\title{
Faktor Risiko Bangkitan Kejang Demam pada Anak
}

\author{
Fuadi, ${ }^{*}$ Tjipta Bahtera, ${ }^{*}$ Noor Wijayahadi** \\ * Bagian Ilmu Kesehatan Anak FK Universitas Diponegoro/RSUP Dr. Kariadi Semarang \\ ** Bagian Farmakologi FK Universitas Diponegoro/RSUP Dr. Kariadi Semarang
}

Latar belakang. Kejang demam dapat mengakibatkan gangguan tingkah laku, penurunan nilai akademik dan sangat mengkhawatirkan orang tua anak. Bila faktor risiko diketahui lebih awal dapat dilakukan pencegahan sedini mungkin akan terjadinya bangkitan kejang demam pada anak.

Tujuan. Membuktikan dan menganalisis faktor demam, usia, riwayat keluarga, riwayat prenatal (usia ibu saat hamil), dan perinatal (usia kehamilan, asfiksia dan berat lahir rendah) sebagai faktor risiko bangkitan kejang demam pada anak.

Metode. Studi kasus kontrol pada 164 anak dipilih secara consecutive sampling dari pasien yang berobat di RS. Dr. Kariadi Semarang periode bulan Januari 2008-Maret 2009. Pasien kejang demam sebagai kelompok kasus 82 anak dan demam tanpa kejang sebagai kelompok kontrol 82 anak. Pengambilan data dari catatan medik dan dilanjutkan wawancara dengan orang tua anak.pada kunjungan rumah. Analisis data dengan tes chi square dan uji multivariat regresi logistik.

Hasil. Didapatkan hubungan yang bermakna antara faktor risiko dengan terjadinya bangkitan kejang demam yaitu faktor demam lebih dari $39^{\circ} \mathrm{C}$ dan faktor usia kurang 2 tahun.

Kesimpulan. Demam lebih dari $39^{\circ} \mathrm{C}$ dan usia kurang dari 2 tahun merupakan faktor risiko bangkitan kejang demam. Sari Pediatri 2010;12(3):142-9.

Kata kunci: kejang demam, faktor risiko

K

ejang demam adalah kejang yang terkait dengan gejala demam dan usia, serta tidak didapatkan infeksi intrakranial ataupun kenaikan suhu tubuh lebih dari $38^{\circ} \mathrm{C}$ rektal atau le-

\footnotetext{
Alamat korespondensi:

Dr. Tjipta Bahtera,, Sp.A(K). Bagian IKA FK UNDIP/RS.Dr. Kariadi. Jl. Dr. Soetomo No. 16-18 Semarang. Telp. 024-8311471/8414296, Fax. 024-8414296.

Dr. Fuadi. E-mail : fuadi06@gmail.com
}

bih $37,8^{\circ} \mathrm{C}$ aksila. ${ }^{3}$ Pendapat para ahli, kejang demam terbanyak terjadi pada waktu anak berusia antara 3 bulan sampai dengan 5 tahun. ${ }^{1}$ Berkisar $2 \%-5 \%$ anak di bawah 5 tahun pernah mengalami bangkitan kejang demam. ${ }^{4,5}$ Lebih dari $90 \%$ kasus kejang demam terjadi pada anak berusia di bawah 5 tahun. ${ }^{6}$ Terbanyak bangkitan kejang demam terjadi pada anak berusia antara usia 6 bulan sampai dengan 22 bulan, ${ }^{7}$ insiden bangkitan kejang demam tertinggi terjadi pada usia 18 bulan. ${ }^{8}$ Di Amerika Serikat dan Eropa prevalensi kejang demam berkisar 2\%-5\%. Di Asia prevalensi kejang 
demam meningkat dua kali lipat bila dibandingkan di Eropa dan di Amerika. Di Jepang kejadian kejang demam berkisar 8,3\% - 9,9\%., ${ }^{9,10}$ Bahkan di Guam insiden kejang demam mencapai $14 \% .{ }^{11}$

Kejang demam merupakan salah satu kelainan saraf tersering pada anak. ${ }^{9}$ Kejang demam dikelompokkan menjadi dua, yaitu kejang demam sederhana dan kejang demam kompleks. ${ }^{9,10,11}$ Faktor-faktor yang berperan da lam risiko kejang demam yaitu, faktor demam, usia, dan riwayat keluarga, dan riwayat prenatal (usia saat ibu hamil), riwayat perinatal (asfiksia, usia kehamilan, dan bayi berat lahir rendah).

Sebagian besar kasus kejang demam sembuh sempurna, sebagian berkembang menjadi epilepsi (2\%$7 \%)^{9}$ dengan angka kematian 0,64\%-0,75\%. ${ }^{0}$ Kejang demam dapat mengakibatkan gangguan tingkah laku serta penurunan intelegensi dan pencapaian tingkat akademik. Beberapa hasil penelitian tentang penurunan tingkat intelegensi paska bangkitan kejang demam tidak sama, ${ }^{12} 4 \%$ pasien kejang demam secara bermakna mengalami gangguan tingkah laku dan penurunan tingkat intelegensi. ${ }^{13}$ Prognosis kejang demam baik, namun bangkitan kejang demam cukup mengkhawatirkan bagi orang tuanya. ${ }^{14}$ Hasil penelitian Van Stuijven Berg ${ }^{15}$ menunjukan bahwa $17 \%$ di antara orang tua anak dengan kejang demam tidak mempunyai pengetahuan tentang kejang, dan 47\%-77\% menganggap anaknya sakit berat dan akan berakhir dengan kematian. Hasil penelitian Parmar dkk, ${ }^{16}$ di India mendapatkan bahwa $77,9 \%$ para orang tua pasien kejang demam tidak mempunyai pengetahuan mengenai kejang demam dan 90\% menganggap anaknya akan meninggal. Atas dasar pertimbangan bahwa, 1) demam memungkinkan terjadi bangkitan kejang demam, kejang demam menurunkan tingkat kecerdasan dan cacat saraf, dan 2) kekhawatiran dan kebingungan orang tua terhadap anaknya tatkala mengalami bangkitan kejang, maka diperlukan tindakan pencegahan terhadap bangkitan kejang demam. Untuk kepentingan tersebut diperlukan pengetahuan tentang cara yang tepat untuk memprediksi terhadap timbulnya bangkitan kejang demam. Perihal tersebut penting dalam rangka penentukan apakah diperlukan pengobatan profilaksis terhadap faktor risiko, dalam rangka memberi nasehat kepada orang tua pasien perihal penyakit anaknya. ${ }^{17,18}$

Tujuan dari penelitian untuk membuktikan faktor derajat tinggi dan lama demam, usia kurang dari dua tahun, riwayat kejang demam pada keluarga, usia ibu saat hamil, usia kehamilan, asfiksia, dan bayi berat lahir rendah merupakan faktor risiko terjadinya bangkitan kejang demam pada anak antara usia 6 bulan -5 tahun. Penelitian bermanfaat secara ilmiah untuk melakukan upaya promotif dan preventif kepada orangtua untuk menurunkan risiko bangkitan kejang demam. Analisis dilakukan terhadap faktor risiko pada bangkitan kejang demam.

\section{Metode}

Penelitian dengan rancangan kasus kontrol, dilakukan selama periode bulan Januari 2008 sampai Maret 2009 di ruang perawatan bagian Ilmu Kesehatan Anak RSUP Dr. Kariadi Semarang. Kriteria inklusi kelompok kasus adalah usia 6 bulan-5 tahun, kejang berhubungan dengan demam (suhu tubuh $>38^{\circ} \mathrm{C}$ ), pasien baru maupun lama, dan orang tua/wali bersedia untuk diikutsertakan dalam penelitian. Kriteria eksklusi kelompok kasus adalah pada pemeriksaan fisik curiga ada infeksi intrakranial, gangguan metabolik dan elektrolit, menggunakan obat anti-konvulsan jangka panjang, developmental delayed, cerebral palsy, riwayat epilepsi, dan data tidak lengkap. Kriteria inklusi dan eksklusi kelompok kontrol sama dengan kelompok kasus, hanya berbeda kriteria inklusi pada kelompok kontrol mengalami demam tanpa disertai bangkitan kejang.

Besar sampel berdasarkan perhitungan adalah 164 anak yang terdiri dari 82 kasus dan 82 kontrol. Pemilihan sampel dengan metode consecutive sampling berdasarkan kedatangan anak umur 6 bulan-5 tahun yang mengalami bangkitan kejang demam dan demam tanpa kejang yang memenuhi kriteria penelitian dan dirawat di Bagian Anak RS Dr. Kariadi Semarang. Pengumpulan data dimulai dengan memilih pasien dengan bangkitan kejang demam yang memenuhi kriteria penelitian, kemudian dicatat data klinis, catatan medik dan wawancara dengan orang tua pasien. Analisis data meliputi analisis deskriptif dan uji hipotesis $\mathrm{x}^{2}$. Besarnya variabel faktor risiko dengan bangkitan kejang demam, dinyatakan sebagai rasio odds. Pengaruh variabel faktor risiko dengan bangkitan kejang demam, dianalisis dengan uji multivariat regresi logistik. Batas kemaknaan adalah apabila $\mathrm{p} \leq 0,05$ dengan interval kepercayaan $95 \%$. 
Fuadi dkk: Faktor risiko bangkitan kejang demam pada anak

\section{Hasil}

Subyek penelitian berjumlah 164 anak umur 6 bulan- 5 tahun, dengan 82 anak kelompok kasus dan 82 anak kelompok kontrol. Data karakteristik umum subyek penelitian pada kelompok kasus dan kontrol tertera pada Tabel 1.

Tabel 1 menunjukkan usia kelompok kontrol rata-rata lebih besar dari kelompok kasus dan jenis kelamin pada kelompok kasus dan kontrol lebih banyak dijumpai anak laki-laki dibanding perempuan.

Tabel 1. Karakteristik umum subyek penelitian pada kelompok kasus dan kontrol

\begin{tabular}{|c|c|c|}
\hline \multirow[t]{2}{*}{ Karateristik anak } & \multicolumn{2}{|c|}{ Kelompok } \\
\hline & Kasus & kontrol \\
\hline Umur rerata $\pm \mathrm{SB}$ (bulan) & $30,67 \pm 12,19$ & $33,26 \pm 12,43$ \\
\hline \multicolumn{3}{|l|}{ Jenis kelamin, n (\%) } \\
\hline Laki-laki & $58(70,7 \%)$ & $47(57,3 \%)$ \\
\hline Perempuan & $24(29,3 \%)$ & $35(42,7 \%)$ \\
\hline
\end{tabular}

\section{Karakteristik faktor-faktor yang berpengaruh terhadap bangkitan kejang demam pada kelompok kasus dan kontrol}

\section{Faktor demam}

Sebagian besar anak pada kelompok kasus yang mengalami demam dengan suhu lebih dari $39^{\circ} \mathrm{C}$ (Tabel 2). Hasil uji statistik menunjukkan adanya hubungan yang bermakna antara kategori distribusi tinggi demam dengan bangkitan kejang demam. Hasil tersebut berarti anak dengan demam lebih $39^{\circ} \mathrm{C}$ mempunyai risiko untuk mengalami demam 4,5 kali lebih besar dibanding anak yang mengalami demam kurang $39^{\circ} \mathrm{C}(\mathrm{CI} 2,33-10,83, \mathrm{p}<0,001)$. Berdasarkan kategori lama demam terlihat pada kelompok kasus sebagian besar mengalami demam kurang dari dua jam. Hasil uji statistik menunjukkan adanya hubungan yang bermakna antara kategori lama demam dengan bangkitan kejang demam. Berarti anak dengan lama demam kurang dari dua jam untuk terjadinya bangkitan kejang demam 2,4 kali lebih besar dibanding anak yang mengalami demam lebih dari dua jam. (CI $1,31-4,59, \mathrm{p}=0,005)$.

\section{Faktor usia}

Pada faktor usia menunjukkan bahwa kelompok kasus dan kontrol sebagian besar mengalami kejang pertama kali pada usia kurang dari dua tahun. Hasil uji statistik menunjukkan hubungan yang bermakna antara usia kurang dua tahun dengan bangkitan kejang demam. Hal ini berarti anak dengan kejang usia kurang dari dua tahun mempunyai risiko bangkitan kejang demam 3,4 kali lebih besar dibanding yang lebih dari dua tahun (CI 1,39-8,30, $\mathrm{p}=0,006$ ) (Tabel 2).

\section{Faktor riwayat kejang dalam keluarga}

\section{Riwayat kejang dalam keluarga (first degree relative)}

Persentase adanya riwayat kejang pada keluarga terdekat (first degree relative) yaitu kedua orang tua ataupun saudara kandung, pada kelompok kasus lebih besar dibanding kelompok kontrol (Tabel 2). Hal ini menunjukkan anak dengan riwayat kejang dalam keluarga terdekat (first degree relative) mempunyai risiko untuk menderita bangkitan kejang demam 4,5 kali lebih besar dibanding yang tidak (CI 1,22-16,65, $\mathrm{p}=0,02)$. Faktor riwayat kejang pada ibu, ayah, dan saudara kandung hasil uji statistik tidak menunjukkan hubungan yang bermakna karena mempunyai sel yang kosong dan $\mathrm{p}>0,05$.

\section{Faktor perinatal dan pascanatal}

Hasil uji statistik menunjukkan tidak ada hubungan yang bermakna antara kategori umur ibu saat hamil dengan bangkitan kejang demam $(p=0,44)$, faktor usia kehamilan preterm dan post term $(\mathrm{p}=0,19$ dan $\mathrm{p}=0,36$ ), dan kejadian asfiksia dan bayi berat lahir rendah ( $\mathrm{p}=0,09$ dan $\mathrm{p}=0,75)$ (Tabel 3).

Faktor tinggi demam dan usia kurang dari dua tahun merupakan faktor risiko terjadinya bangkitan kejang demam pada anak (Tabel 4). Anak dengan demam lebih besar dari $39^{\circ} \mathrm{C}$ memiliki risiko $10 \mathrm{kali}$ lebih besar untuk menderita bangkitan kejang demam dibanding dengan anak yang demam kurang $39^{\circ} \mathrm{C}$. Anak usia kurang dari dua tahun mempunyai risiko 8,9 kali lebih besar dibanding anak yang lebih dari dua tahun. 
Fuadi dkk: Faktor risiko bangkitan kejang demam pada anak

Tabel 2. Karakteristik demam kelompok kasus dan kontrol

\begin{tabular}{|c|c|c|c|c|}
\hline \multirow[t]{2}{*}{ Karateristik } & \multicolumn{2}{|c|}{ Kelompok, n (\%) } & \multirow[b]{2}{*}{ OR (95\% CI) } & \multirow[b]{2}{*}{$\mathrm{p}$} \\
\hline & $\begin{array}{c}\mathrm{KD} \\
(\mathrm{n}=82)\end{array}$ & $\begin{array}{l}\text { Non-KD } \\
(\mathrm{n}=82)\end{array}$ & & \\
\hline Tinggi demam $\left({ }^{0} \mathrm{C}\right)$ & & & $4,54(2,33-8,83)$ & $<0,001^{*}$ \\
\hline$-\geq 39$ & $50(61,0)$ & $21(25,6)$ & & \\
\hline$-<39$ & $32(39,0)$ & $61(74,4)$ & & \\
\hline Lama demam (jam) & & & $2,45(1,31-4,59)$ & $0,005^{*}$ \\
\hline$-<2$ & $48(58,5)$ & $30(36,6)$ & & \\
\hline$-\geq 2$ & $34(41,5)$ & $52(63,4)$ & & \\
\hline Usia pertama kali kejang (tahun) & & & $3,40(1,39-8,30)$ & $0,006^{*}$ \\
\hline$-<2$ & $66(80,5)$ & $17(54,8)$ & & \\
\hline$->2$ & $16(19,5)$ & $14(45,2)$ & & \\
\hline \multicolumn{5}{|l|}{$\begin{array}{l}\text { Anggota keluarga ada } \\
\text { yang kejang demam }\end{array}$} \\
\hline$-Y a$ & $12(14,6)$ & $3(3,7)$ & & \\
\hline -Tidak & $70(85,4)$ & $79(96,3)$ & $4,51(1,22-16,65)$ & $0,02^{* * *}$ \\
\hline \multicolumn{5}{|l|}{$\begin{array}{l}\text { Penderita kejang demam } \\
\text { dalam keluarga }\end{array}$} \\
\hline \multicolumn{5}{|l|}{ Ibu } \\
\hline Ya & $6(7,3)$ & $0(0)$ & & \\
\hline Tidak & $76(92,7)$ & $82(50)$ & - & $0,02^{* * *}$ \\
\hline \multicolumn{5}{|l|}{ Ayah } \\
\hline Ya & $1(1,2)$ & $0(0)$ & & \\
\hline Tidak & $81(98,2)$ & $82(100)$ & - & $0,02^{* * *}$ \\
\hline \multicolumn{5}{|l|}{ Saudara kandung } \\
\hline $\mathrm{Ya}$ & $5(6,1)$ & $3(3,7)$ & & \\
\hline Tidak & $77(93,9)$ & $79(96,3)$ & $1,71(0,40-7,40)$ & $0,72^{*}$ \\
\hline
\end{tabular}

\section{Pembahasan}

Demam merupakan faktor utama timbul bangkitan kejang demam. Pada penelitian kami batas tinggi demam $39^{\circ} \mathrm{C}$ sebagai rata-rata, dengan rentang suhu $\left(38,9^{\circ} \mathrm{C}-39,9^{\circ} \mathrm{C}\right)$. Ketentuan tersebut berdasarkan pada penelitian sebelumnya bahwa bangkitan kejang demam terbanyak terjadi pada kenaikan suhu tubuh berkisar $38,9^{\circ} \mathrm{C}-39,9^{\circ} \mathrm{C}$ yaitu $40 \%-56 \%, 20 \%$ suhu di atas $40^{\circ} \mathrm{C}$ dan $11 \% 37^{\circ} \mathrm{C}-38,9^{\circ} \mathrm{C} .{ }^{17}$ Perubahan kenaikan temperatur tubuh berpengaruh terhadap nilai ambang kejang dan eksitabilitas neural, karena kenaikan suhu tubuh berpengaruh pada kanal ion dan metabolisme seluler serta produksi ATP 19,20,21 Setiap kenaikan suhu tubuh satu derajat Celsius akan meningkatkan metabolisme karbohidrat 10\%-15\%, sehingga dengan adanya peningkatan suhu akan mengakibatkan peningkatan kebutuhan glukosa dan oksigen. ${ }^{18,20}$ Pada demam tinggi akan mengakibatkan hipoksia jaringan termasuk jaringan otak. Pada keadaan metabolisme di siklus Creb normal, satu molekul glukosa akan menghasilkan 38 ATP. Sedangkan pada keadaan hipoksi jaringan metabolisme berjalan anaerob, satu molukul glukosa hanya akan menghasilkan 2 ATP, sehingga pada keadaan hipoksi akan kekurangan energi dan mengganggu fungsi normal pompa $\mathrm{Na}^{+}$ dan reuptake asam glutamat oleh sel g1 ia. ${ }^{21}$ Kedua hal tersebut mengakibatkan masuknya $\mathrm{Na}^{+}$ke dalam sel meningkat dan timbunan asam glutamat ekstrasel. Timbunan asam glutamat ekstrasel akan mengakibatkan peningkatan permeabilitas membran sel terhadap ion $\mathrm{Na}^{+}$sehingga semakin meningkatkan ion $\mathrm{Na}^{+}$masuk ke dalam sel. Ion $\mathrm{Na}^{+}$ke dalam sel dipermudah pada keadaan demam, sebab demam akan meningkatkan 
Fuadi dkk: Faktor risiko bangkitan kejang demam pada anak

Tabel 3. Riwayat kehamilan maupun persalinan anak pada kelompok kasus dan kontrol

\begin{tabular}{|c|c|c|c|c|}
\hline \multirow[t]{2}{*}{ Variabel } & \multicolumn{2}{|c|}{ Kelompok, n (\%) } & \multirow[t]{2}{*}{$\mathrm{p}$} & \multirow{2}{*}{$\begin{array}{c}\text { OR } \\
(95 \% \mathrm{CI})\end{array}$} \\
\hline & $\begin{array}{c}\mathrm{KD} \\
(\mathrm{n}=82)\end{array}$ & $\begin{array}{c}\text { Non-KD } \\
(\mathrm{n}=82)\end{array}$ & & \\
\hline \multicolumn{5}{|c|}{ Umur ibu saat hamil (tahun) } \\
\hline$-<20$ & $7(8,5)$ & $12(14,6)$ & $0,44^{*}$ & $0,6(0,2-1,5)$ \\
\hline$-20-35$ & $66(80,5)$ & $63(76,8)$ & & $1,0($ reference $)$ \\
\hline$->35$ & $9(11,0)$ & $7(8,5)$ & & $1,2(0,4-3,5)$ \\
\hline \multicolumn{5}{|c|}{ Lahir kurang bulan (preterm) } \\
\hline - Aterm & $77(93,9)$ & $76(92,7)$ & $0,19^{*}$ & $4,0(0,44-37,09)$ \\
\hline - Preterm & $1(1,2)$ & $4(4,9)$ & & \\
\hline \multicolumn{5}{|c|}{ Lahir lebih bulan (posterm) } \\
\hline - Aterm & $77(93,9)$ & $76(92,7)$ & $0,36^{*}$ & $0,51(0,09-2,85)$ \\
\hline - Post term & $4(4,9)$ & $2(2,4)$ & & \\
\hline \multicolumn{5}{|l|}{ Saat lahir } \\
\hline - Asfiksia & $4(4,9)$ & $10(12,2)$ & $0,09^{*}$ & $0,37(0,11-1,23)$ \\
\hline - Tidak asfiksia & $78(95,1)$ & $72(87,8)$ & & \\
\hline \multicolumn{5}{|l|}{ Berat lahir (gram) } \\
\hline$-<2500$ & $44(53,7)$ & $41(50)$ & $0,75^{*}$ & $1,16(0,63-2,14)$ \\
\hline$-\geq 2500$ & $38(46,3)$ & $41(50)$ & & \\
\hline
\end{tabular}

Tabel 4. Hasil uji regresi logistik faktor-faktor risiko bangkitan kejang demam

\begin{tabular}{lcccr}
\hline Faktor risiko & Crude OR & $\begin{array}{c}\text { Adjusted } \\
\text { OR }\end{array}$ & $95 \% \mathrm{CI}$ & \multicolumn{1}{c}{$\mathrm{p}$} \\
\hline Tinggi demam & 4,5 & 10,0 & $1,01-99,23$ & 0,049 \\
Lama demam & 2,4 & 0,1 & $0,01-1,04$ & 0,054 \\
Usia kurang dari 2 tahun & 3,4 & 8,9 & $4,66-17,09$ & $<0,001$ \\
Riwayat keluarga (first degree & 4,5 & 5,8 & $0,83-40,52$ & 0,076 \\
relative) & 0,4 & 1,4 & $0,26-7,85$ & 0,674 \\
Asfiksia & & & & \\
\hline
\end{tabular}

mobilitas dan benturan ion terhadap membran sel. ${ }^{21,22}$ Perubahan konsentrasi ion $\mathrm{Na}^{+}$intrasel dan ekstrasel tersebut akan mengakibatkan perubahan potensial membran sel neuron sehingga membran sel dalam keadaan depolarisasi. Disamping itu demam dapat merusak neuron GABA-ergik sehingga fungsi inhibisi terganggu. ${ }^{23,24}$ Berdasarkan uraian tersebut dapat disimpulkan bahwa demam tinggi dapat mempengaruhi perubahan konsentrasi ion natrium intraselular akibat $\mathrm{Na}^{+}$influx sehingga menimbulkan keadaan depolarisasi, disamping itu demam tinggi dapat menurunkan kemampuan inhibisi akibat kerusakan neuron GABA-nergik. ${ }^{23,25}$ Pada penelitian kami, kelompok kasus diketahui sebagian besar anak dengan bangkitan kejang demam didahului lama demam kurang dua jam. Setiap kenaikan suhu $0,3^{\circ} \mathrm{C}$ secara cepat akan menimbulkan discharge di daerah oksipital, discharge di daerah oksipital dapat dilihat dan hasil rekaman EEG. Kenaikan mendadak suhu tubuh menyebabkan kenaikan kadar asam glutamat dan menurunkan kadar glutamin tetapi sebaliknya kenaikan suhu tubuh secara pelan tidak menyebabkan kenaikan kadar asam glutamat. Perubahan glutamin menjadi asam glutamat dipengaruhi oleh kenaikan suhu tubuh. Asam glutamat merupakan eksitator, sedangkan GABA sebagai inhibitor tidak dipengaruhi oleh kenaikan suhu tubuh mendadak. ${ }^{23,25}$

Usia pertama kali kejang pada kelompok kasus diketahui sebagian besar adalah kurang dari dua tahun. Pada keadaan otak belum matang reseptor untuk asam 
glutamat baik ionotropik maupun metabotropik sebagai reseptor eksitator padat dan aktif, sebaliknya reseptor GABA sebagai inhibitor kurang aktif, sehingga otak belum matang eksitasi lebih dominan dibanding inhibisi ${ }^{26,27}$ Corticotropin releasing hormon (CRH) merupakan neuropeptid eksitator, berpotensi sebagai prokonvulsan. Pada otak belum matang kadar CRH di hipokampus tinggi, berpotensi untuk terjadi bangkitan kejang apabila terpicu oleh demam. ${ }^{24}$ Mekanisme homeostasis pada otak belum matang masih lemah, akan berubah sejalan dengan perkembangan otak dan pertambahan umur, oleh karena pada otak belum matang neural $\mathrm{Na}^{+} / \mathrm{K}^{+}$ATP ase masih kurang. Pada otak yang belum matang regulasi ion $\mathrm{Na}^{+}, \mathrm{K}^{+}$, dan $\mathrm{Ca}^{++}$belum sempurna, sehingga mengakibatkan gangguan repolarisasi pasca depolarisasi dan meningkatkan eksitabilitas neuron. ${ }^{25}$ Oleh karena itu, pada masa otak belum matang mempunyai eksitabilitas neural lebih tinggi dibandingkan otak yang sudah matang. Pada masa ini disebut sebagai developmental window dan rentan terhadap bangkitan kejang. Eksitator lebih dominan dibanding inhibitor, sehingga tidak ada keseimbangan antara eksitator dan inhibitor. Anak mendapat serangan bangkitan kejang demam pada umur awal masa developmental window mempunyai waktu lebih lama fase eksitabilitas neural dibanding anak yang mendapat serangan kejang demam pada umur akhir masa developmental window. Apabila anak mengalami stimulasi berupa demam pada otak fase eksitabilitas akan mudah terjadi bangkitan kejang. Developmental window merupakan masa perkembangan otak fase organisasi yaitu pada waktu anak berumur kurang dari dua tahun Sehingga anak yang mengalami serangan kejang demam pada umur di bawah dua tahun mempunyai risiko terjadi bangkitan kejang demam berulang. ${ }^{27}$

Riwayat keluarga dengan kejang demam adalah salah satu faktor risiko yang dilaporkan untuk terjadi bangkitan kejang demam. Keluarga dengan riwayat pernah menderita kejang demam sebagai faktor risiko untuk terjadi kejang demam pertama adalah kedua orang tua ataupun saudara kandung (first degree relative). Belum dapat dipastikan cara pewarisan sifat genetik terkait dengan kejang demam, apakah autosomal resesif atau autosomal dominan. Penetrasi autosomal dominan diperkirakan sekitar $60 \%-80 \% .^{28,29}$ Bila kedua orangnya tidak mempunyai riwayat pernah menderita kejang demam maka risiko terjadi kejang demam hanya 9\%. Apabila salah satu orang tua penderita dengan riwayat pernah menderita kejang demam mempunyai risiko untuk terjadi bangkitan kejang demam 20\%-22\%. Apabila ke dua orang tua penderita tersebut mempunyai riwayat pernah menderita kejang demam maka risiko untuk terjadi bangkitan kejang demam meningkat menjadi 59\%-64\%. ${ }^{30}$ Kejang demam diwariskan lebih banyak oleh ibu dibandingkan ayah, $27 \%$ berbanding $7 \% .{ }^{31}$ Penelitian Hauser dkk, ${ }^{31}$ di Amerika menunjukkan bahwa kasus kejang dernam mempunyai saudara pernah menderita kejang demam mempunyai risiko 2,7\% (CI 95\% 2.0-3.6), sedangkan apabila pasien tersebut mempunyai salah satu orang tua dengan riwayat pernah menderita kejang demam maka risiko untuk terjadi bangkitan kejang demam meningkat menjadi 10\% (CI 95\% 6.3-15) dan apabila ke dua orang tua penderita tersebut mempunyai riwayat pernah menderita kejang demam risiko tersebut meningkat menjadi 20\% (CI 95\% 9.6-36.8). Peneliti mendapatkan bahwa kasus kejang demam pertama dengan keluarga mempunyai riwayat pernah menderita kejang demam, masingmasing ibu $7,3 \%$, ayah $1,2 \%$, saudara kandung $6,1 \%$ dan first degree relative sebanyak 14,6\%. Riwayat keluarga (first degree relative) pernah menderita kejang demam bermakna sebagai faktor risiko untuk timbul bangkitan kejang demam dengan OR 4,51 (CI 95\% 1,22-16,65, $\mathrm{p}=0.02$ ).

Proporsi kategori umur ibu hamil 20-35 tahun pada kelompok kasus lebih besar dibanding dengan proporsi kategori umur ibu hamil kurang 20 tahun dan lebih dari 35 tahun. Kemungkinan faktor usia ibu saat hamil, tidak menyebabkan keadaan hipoksia pada bayi karena pada ibu subyek penelitian sedikit sekali yang menderita penyakit seperti hipertensi, eklamsi, diabetes melitus dan penyakit jantung. Hasil penelitian sebelumnya melaporkan bahwa umur yang baik untuk melahirkan adalah antara 20-34 tahun. Hal ini berhubungan dengan kehamilan pada umur lebih 35 tahun berisiko tinggi untuk terjadi gawat janin berupa retardasi pertumbuhan intra uteri dan hipoksia. Ibu yang hamil pada usia tersebut mulai sering menderita penyakit seperti hipertensi, eklamsi, kanker mulut rahim, kencing manis, dan penyakit jantung. Pada keadaan ini jalan lahir kurang elastis dibandingkan sebelumnya, sehingga mengakibatkan persalinan yang sulit dan lama. Hal ini ditambah menurunnya kekuatan ibu untuk mengeluarkan bayi karena faktor umur maupun pengaruh penyakit yang dideritanya. Sehingga kemungkinan dapat melahirkan bayi dengan asfiksia dan atau mengalami trauma lahir yang berupa perdarahan intra kranial lebih besar, yang 
dapat berlanjut menjadi epilepsi di kemudian hari. Untuk itu perlu penelitian lanjutan dengan subyek penelitian yang lebih besar, agar lebih menggambarkan keadaan sebenarnya.

Proporsi faktor usia kehamilan aterm pada kelompok kasus lebih besar dibanding dengan preterm dan post term. Kemungkinan faktor usia kehamilan pada penelitian kami tidak signifikan karena tidak menyebabkan keadaan hipoksia pada bayi dan jumlah subyek penelitian yang masih kurang, sehingga diperlukan penelitian lanjutan dengan subyek penelitian yang lebih besar untuk lebih menggambarkan keadaan yang sebenarnya. Bayi yang lahir preterm perkembangaan organorgan tubuh kurang sempurna sehingga belum dapat berfungsi dengan sempurna. Pada kelompok kasus proporsi anak dengan asfiksia saat lahir lebih sedikit dibanding dengan tanpa asfiksia, akan tetapi tidak ada hubungan antara kejadian asfiksia dengan bangkitan kejang demam.

Hipoksia dapat mengakibatkan rusaknya fungsi inhibisi dan atau meningkatnya fungsi eksitasi neuron, sehingga mudah timbul kejang apabila ada rangsangan yang memadai. Asfiksia dapat menimbulkan lesi pada hipokampus dan lesi tersebut dapat menjadi fokus epileptogen. Pada asfiksia dapat terjadi hipoksia iskemia ensefalopati yang berakibat kelainan neuropatologis. Kelainan neurologis yang ditimbulkan dapat berupa gangguan saraf yang tidak progresif seperti kejang, retardasi mental, gangguan perkembangan psikomotor dan kelainan motor. Hipoksia dan iskemia akan menyebabkan peninggian $\mathrm{Na}^{+}$intraselular sehingga terjadi edema otak yang dapat menyebabkan kerusakan otak. Daerah yang sensitif tcrhadap hipoksia adalah inti-inti pada batang otak, thalamus, dan kollikulus inferior, sedangkan terhadap iskemia adalah 'watershead area' yaitu daerah hemisfer otak yang mendapat vaskularisasi paling sedikit. Pada penelitian sebelumnya faktor asfiksia dapat menjadi faktor risiko terjadinya bangkitan kejang demam pada anak. Faktor asfiksia agaknya tidak menjadi faktor risiko terjadinya bangkitan kejang demam kemungkinan karena peneliti tidak menjelaskan apakah bayi menderita asfiksia ringan, sedang atau berat. Subyek penelitian kemungkinan hanya asfiksia ringan, bukan asfiksia sedang atau berat, yang dapat menyebabkan keadaan hipoksia pada bayi dan dapat memudahkan timbulnya bangkitan kejang demam.

Pada kelompok kasus sebagian besar anak lahir dengan berat kurang 2500 gram. Bayi yang lahir dengan berat badan rendah dapat mengalami hipoksia iskemia, dan atau kemungkinan mengalami perdarahan intraventrikular. Kemungkinan faktor berat lahir pada penelitian kami tidak signifikan karena peneliti tidak menjelaskan apakah bayi mempunyai bayi berat lahir rendah (<2500 gram), sangat rendah (<1500 gram) atau amat sangat rendah $(<1000$ gram $)$. Subyek penelitian berat lahir rendah bukan berat lahir sangat rendah atau amat sangat rendah. Berat lahir sangat rendah atau amat sangat rendah mempunyai risiko keadaan hipoksia pada bayi dan dapat memudahkan timbulnya bangkitan kejang demam.

Penelitian ini belum dapat menjelaskan peran dari seluruh faktor risiko yang diteliti dan beberapa faktor risiko belum dapat disimpulkan sebagai faktor risiko ataupun faktor protektif. Hal tersebut disebabkan keterbatasan, 1) Rancangan penelitian kasus kontrol yang bersifat retrospektif, sehingga recall bias tidak bisa dihindarkan, 2) Keterbatasan informasi pada catatan medik dan tidak semua responden mempunya catatan medik pada waktu hamil dan persalinan. Untuk memperkecil bias tersebut dilakukan teknik wawancara yang dapat menggali ingatan resoponden, penggunaan kuesioner yang telah teruji oleh peneliti lain dan uji coba kuesioner untuk mengukur reliabitas pertanyaan yang kemungkinan sulit mendapatkan data pada catatan medik (kehamilan dengan hipertensi, asfiksia, partus lama, dan berat lahir).

Disimpulkan bahwa demam tinggi lebih dari $39^{\circ} \mathrm{C}$ dan usia kurang dari dua tahun merupakan faktor risiko terjadinya bangkitan kejang demam. Disarankan edukasi kepada orang tua, jika anak menderita demam jangan sampai menjadi demam tinggi yang dapat memicu bangkitan kejang demam, dan dapat mengurangi kecemasan orang tua. Hal ini untuk menurunkan morbiditas, juga untuk menghindarkan adanya dampak buruk bangkitan kejang demam pada anak. Perlu dilakukan penelitian selanjutnya dengan jumlah subyek yang lebih besar serta mengikutsertakan variabel-variabel lain yang belum diteliti untuk memperoleh hasil yang lebih akurat.

\section{Daftar pustaka}

1. Hirtz DG, Nelson KB. Febrile seizures. Dalam: David RB. Pediatric neurology for the clinician. Norwalk: Appleton \& Lange;1992.h.557-66. 
2. Seki T, Hara M. Clinical aspects of febrile convulsions. Asian Med J 1993;36:533-43.

3. Consensus Development Panel. Febrile seizures: longterm management of children with fever-associated seizures. Pediatr rev 1981;2:209-12.

4. Hulihan J F. Seizures in special populations. Postgraduate Medicine 1997;102:165-75.

5. Berman RE, Kliegman RM Jenson HB. Nelson textbook of pediatrics. Edisi ke-16. Philadelphia: WB Saunders Co;2000.h.1818-9.

6. Arzimanoglou A, Guerrini R. Aicardi J, penyunting. Aicardi's epilepsy in children. Edisi ke-3. Philadelphia: Lippincott Williams \& Wilkins;2004.h.220-34.

7. Farwell JR, Blacner G, Sulzbacker S. First febrile seizures characteristics of the child, the seizures and the illness. Clin Pediatr 1994;33:263-7.

8. Hauser W A. The prevalence and incidence of convulsive disorders in children. Epilepsia 1994:35 (suppl. 2): SI-S 6.

9. Hirtz G D. Febrile seizure. Pediatr Rev 1997;18:5-8.

10. Berg AT, Shinnar S. Complex febrile seizures. Epilepsia 1996;37:126-33.

11. Knudsen FU. Febrile seizures: treatment and prognosis. Epilepsia 2000;41: 2-9.

12. Hirtz D.Cognitive Outcome of febrile seizures. Dalam: Baram TZ, Shinnar S, penyunting. Febrile seizures. San Diego: Academic press;2002.h.53-60.

13. Verity C M, Greenwood R, Golding J. Long term intellectual and behavioral outcomes of children with febrile convulsions. N Engl J Med 1998;338:1723-8.

14. Balslev T. Parental reactions to children first febrile convulsion. Acta Paediatr Scand 1991;80:446-69

15. Van Stuijvenberg M, de Vos S, Tjiang G C, Steyerberg E W, Derksen-Luben G, Moll H A. Parents fear regarding fever and febrile seizures. Acta Paediatr 1999;88:61822.

16. Parmar RC, Sahu DR. Bavdekar SB. Knowledge attitude and practices of parents of children with febrile convulsion. J Postgrad Med 2001;47:19-23.

17. Gonzalez Del Rey JA. Febril seizures. Dalam: Barken RM, penyunting. Pediatric Emergency Medicine. Edisi ke-2. St Louis: Mosby;1997.h.1017-9.

18. Budiarto G. Patofisiologi epilepsi. Dalam: Penatalaksanaan kejang yang rasional. Surabaya: Gramik FK UNAIR;1998.h.1-20.

19. Hypoxic-Ischemic Encephalopathy: Biochemical and physiological aspects. Dalam: Volve JJ, penyunting. Neurology of the New Born. Edisi ke-4. Philadelphia:
WB Saunders Co; 2001.h.217-64.

20. Harimoto T, Nagao H, Yoshimatsu M, Yoshida $\mathrm{K}$, Matsuda H. Pathogenic role of glutamate in hyperthermia-induced seizures. Epilepsia 1993;34:44752.

21. Gradnner D K. Membran: struktur, susunan \& fungsinya. Dalam: Ronardi D H, Oswari J, penyunting. Biokimia Harper (alih bahasa) cetakan ke 1. Jakarta: Penerbit Buku Kedokteran EGC; 1995.h.529-50.

22. Chen K, Baram T Z, Soltesz I. Febrile seizures in the developing brain result in persistent modification of neuronal excitability in limbic circuits. Nat Med 1999;5: 888-94.

23. Trans V Hatelshi CG, Xin Yan X, Bitram TZ. Effect of bloking GABA degradation on corticotrophin Releasing Hormon Gen expression in Selected region. Epilepsia 1999; 40:1170.

24. Chen Y, Beder RA, Baram TZ. Novel and transient populations of corticotrophin releasing hormone expressing neurons in developing hippocampus suggest unique functional roles: A quantitative spatiotemporal analysis. J Neurosc In Press, 2001.

25. Haglun M M, Schwartzkroin P A. Role of Na-K pump potassium regulation IPSPs in seizures and spreading depression in immature rabbit hippocampal slices. J Neurophysiol 1990;63:225-39.

26. Berg AT. Recurrent Febril Seizures in Baram FZ, Sinnar $S$, penyunting. Febril seizures. San Diego: Academic Pres; 2002.h.37-49.

27. Johnson GW, Kugler SL, Stenroos ES, Meulener MC, Rangwalla, Johnson TW dkk. Pedigree analysis in families with febrile seizures. Am J Med Genet 1996;61:345-52.

28. Kugler SL, Johnson WG. Genetics of the febrile seizure susceptibility trait. Brain Development 1998;20:26574.

29. Singh R, Sceffer IE, Crossland K, Bercovic SF. Generalized epilepsy with febrile seizures plus: A common chillhood-onset genetic epilepsy syndrome. Ann Neurol 1999;45:75-81.

30. Menkes JH, Sankar R. Paroxysmal Disorders. Dalam:. Menkes JH, Sarnat BH, penyunting. Child neurology. Edisi ke-6. Philadelphia: Lippincott Williams \& Wilkins JR; 2000.h.987-91.

31. Hauser WA, Anneger JE, Anderson E, Kurland LT. The risk of seizures disorders among relatives of children with ferible convulsions. Neurology 1985;35:126873. 